\title{
Chronic effects of suspended solids on gill structure, osmoregulation, growth, and triiodothyronine in juvenile green grouper Epinephelus coioides
}

\author{
D. W. T. Au, C. A. Pollino, R. S. S. Wu*, P. K. S. Shin, S. T. F. Lau, J. Y. M. Tang \\ Centre for Coastal Pollution and Conservation, City University of Hong Kong, Tat Chee Avenue, Kowloon, \\ Hong Kong SAR, China
}

\begin{abstract}
Despite suspended solids being an important water-quality parameter in the regulatory process, very little is known about the risks of prolonged exposure to high concentrations of suspended solids in fish, especially marine species. In this study, the green grouper Epinephelus coioides, an important mariculture species with a wide geographic distribution, was exposed to various concentrations $\left(0,50,100,200,1000\right.$ and $\left.2000 \mathrm{mg} \mathrm{l}^{-1}\right)$ of suspended solids for $6 \mathrm{wk}$. The results showed that exposure was not lethal at environmentally realistic concentrations, and no changes in food intake, growth and RNA:DNA ratio were observed. However, damages to gill structure, including epithelium lifting, hyperplasia in the pillar system, and reduction of epithelial volume, were clearly evident, and strongly correlated with suspended solid concentration exposure. Despite the observation that serum osmolarity and haematocrit values did not change, $\mathrm{Na}^{+}, \mathrm{K}^{+}$-ATPase activities and chloride cells of the gill lamellae were altered, indicating that fish were experiencing osmoregulatory stress. Reduction in levels of free triiodothyronine (T3) in serum further confirmed that fish were experiencing physiological stress with suspended solids exposure. The overall results suggested that prolonged exposures can cause sub-lethal stress and compromise fish health, even though the high suspended solids we delivered were in concentrations that have been reported in coastal environments as not lethal to green grouper.
\end{abstract}

KEY WORDS: Suspended solids · Grouper · Gill structure - Triiodothyronine · Osmoregulation · Growth $\cdot$ RNA:DNA ratio

Resale or republication not permitted without written consent of the publisher

\section{INTRODUCTION}

Suspended solids (SS) in the marine environment may arise from natural sources such as sediment loads from terrestrial/river runoff, or anthropogenic activities such as discharges of sewage and industrial wastes, dredging, dumping and land reclamations. Increase in SS in the marine environment is considered to be an important environmental stressor that can cause significant degradation of aquatic ecosystems. Indeed, SS is an important parameter in water quality monitoring, pollution control and environmental impact assessment (EIFAC 1964, USEPA 1986, CCREM 1987). Most of our current knowledge concerning effects of SS on fish are based on freshwater salmonid species (Lloyd 1987), which have shown that elevated concentrations of SS can increase mortality and cause adverse effects, including abrasion of gills, reduction in feeding rates, avoidance of $\mathrm{SS}$, cough responses, and increased susceptibility to disease (Bruton 1985, Redding et al. 1987, Newcombe \& MacDonald 1991, Servizi \& Martens 1991, Martens \& Servizi 1993, Metzeling et al. 1995, DFO 2000).

Studies on North American freshwater fish have found that the concentrations of SS required to kill fish over short time periods typically range from hundreds to hundreds of thousands $\mathrm{mg} \mathrm{l}^{-1}$, whereas concentrations that cause sublethal effects are often in the tens to hundreds of $\mathrm{mg} \mathrm{l}^{-1}$ (Lake \& Hinch 1999, DFO 2000). For example, uncontaminated clay at $2000 \mathrm{mg} \mathrm{l}^{-1}$ was 
not acutely toxic to zebrafish Danio rerio (Van den Belt et al. 2000). Likewise, a previous study using 3 native Hong Kong species found $48 \mathrm{~h}$ exposures of $5000 \mathrm{mg}$ $\mathrm{SS}^{-1}$ did not cause mortality to the mangrove snapper Lutjanus argentimaculatus, the shrimp Metapenaeus ensis and the amphipod Melita longidactyla (CCPC 2001). Notably, existing information on effects of SS is based on acute exposure experiments, and mostly on freshwater salmonid fish. Very little scientific information is available on chronic responses of fish exposed to high concentrations of SS for extended periods, and virtually nothing is known about SS effects to marine non-salmonid species (Wilber \& Clarke 2001). Acute exposure to high concentrations of suspended solids may affect salmonid fish by clogging or coating of gills, causing coughing, respiratory stress and mortality (Hughes \& Morgan 1973, Servizi \& Gordon 1990, Newcombe \& MacDonald 1991, Servizi \& Martens 1991). The early work of Hughes \& Morgan (1973) found thickening of the gill epithelium in trout acutely exposed to high levels of SS, which eventually caused fusion of the adjacent lamella, although concentration and duration of exposure causing these histopathological symptoms are not known. In contrast, Lake \& Hinch (1999) found gills of coho salmon Oncorhynchus kisutch were neither visually affected nor clogged with suspended sediment after exposure to $250 \mathrm{mg} \mathrm{SS} \mathrm{l}^{-1}$ for $96 \mathrm{~h}$.

Being the major organ for respiration and osmoregulation (Hughes \& Morgan 1973), fish gills are directly exposed to, and affected by, suspended solids in the water (Mallatt 1985, Laurent \& Perry 1991, Perry \& Laurent 1993). Damage in integrity of gill lamellae is likely to reduce capacity for oxygen transfer and ammonia excretion, and lead to respiratory stress and ammonia intoxication (Randall \& Daxboeck 1984, Randall \& Wright 1987). Chloride cells and the associated membrane-bound enzyme $\mathrm{Na}^{+}, \mathrm{K}^{+}$-ATPase are responsible for osmoregulation (Karnaky et al. 1976), and damage to these components will upset the salt-water balance and cause osmotic stress to fish (McCormick 1993). However, little is known about how SS can cause cellular damage and whether SS may cause osmoregulation stress to fish (Lake \& Hinch 1999). If physiological disturbances and cytological alterations occur, they should be eventually manifested as stress and possible growth impairment; in turn, this will reduce the fitness of fish in their natural environments. Although these hypotheses have never been tested on marine fish, these scientific data are clearly important in deriving marine water quality criteria of an acceptable level for SS. Furthermore, it is generally believed that SS plumes caused by dredging and dumping sediments may affect fish, yet few studies have been conducted to measure the response of marine fish to a range of concentrations and exposure durations relevant to dredging and dumping (see review by Wilber \& Clark 2001). The paucity of data makes it difficult to provide a scientific assessment on risk of dumping and dredging.

In this study, the green grouper Epinephelus coioides (an important mariculture species that has a wide distribution in the Indo-Pacific) was exposed continuously to various concentrations of suspended sediment for $6 \mathrm{wk}$. We hypothesise that chronic exposure to elevated levels of SS will cause histopathological and ultrastructural changes of the gill, alter $\mathrm{Na}^{+}, \mathrm{K}^{+}-$ ATPase activity and affect osmoregulation of fish. It is further hypothesised that chronic exposure to high levels of SS will cause chronic stress to the fish, as indicated by an elevation of the hormone triiodothyronine (T3) and reduction in muscle RNA to DNA ratios and growth.

\section{MATERIALS AND METHODS}

Exposure experiments. The sediment used for exposure experiments was collected from a clean site (Kau Sai Chau) in Hong Kong using a van Veen grab. Concentrations of cadmium, chromium, copper, lead and zinc in the sediment were below the Lower Chemical Exceedance Level of 1.5, 80, 65, 75 and $200 \mathrm{mg} \mathrm{kg} \mathrm{l}^{-1}$ dry wt respectively, adopted in the classification of sediment quality in Hong Kong (EPD 2002). Sediment was air-dried, ground and passed through a $0.5 \mathrm{~mm}$ sieve to ensure uniformity of particle size. Green grouper Epinephelus coioides (length $9.4 \pm 0.2 \mathrm{~cm}$ ) were purchased from a local fish farm and acclimated for $48 \mathrm{~h}$ prior to experimentation. Seawater used for acclimation and experiments $(30 \%)$ was filtered through a sandactivated charcoal-UV filter before use.

Six suspended sediment concentrations $(0,50,100$, 200, 1000 and $2000 \mathrm{mg} \mathrm{l}^{-1}$ ) were set up, with 4 replicates for each concentration. Each replicate contained 5 fish in a 301 plexiglass tank with 201 of test solution. To ensure that fish were exposed to a homogenous suspension of sediment throughout the exposure period, a counter current was generated by installing 2 submersible venturi pumps (NOVA SICCE) in opposite directions on both sides of each tank. The test was conducted at $20 \pm 0.1^{\circ} \mathrm{C}$, with full aeration over the test period of $6 \mathrm{wk}$. For each day during the 6 wk exposure period, fish were transferred from the test tank to a tank containing seawater only, fed to satiation with shrimp meat for $15 \mathrm{~min}$, and returned to the test tank. The amount of feed consumed by fish in each replicate tank, as well as mortality, was recorded daily. Test solutions in aquaria were $100 \%$ replaced every $48 \mathrm{~h}$ to prevent the build-up of wastes and ammonia. 
Weight of each fish in the control and treatment tanks was measured at the commencement of the exposure, and also at weekly intervals. A water sample was collected from a randomly selected tank from each level of treatment every $48 \mathrm{~h}$ for determination of suspended solids. To ensure accurate measurements of suspended solid concentrations within the test tank, and that the great majority of sediment in the experimental tank was in suspension, water samples were collected from 3 different points of the test tank and combined for analysis. This provided an estimation of SS in water for each nominal concentration, in view of the difficulty in creating a totally homogeneous level in the water column. Temperature and dissolved oxygen were measured using a YSI Model 58 dissolved oxygen meter equipped with a temperature sensor, salinity was measured using a refractometer Model S-10 (Shibuya Optical), and pH using a HI 8424 microcomputer pH meter (Hanna Instruments). All meters were calibrated before use. Total and un-ionised ammonia were determined according to APHA (1995) in 1 replicate tank of each treatment daily.

The series of $0,50,100,200,1000$ and $2000 \mathrm{mg} \mathrm{SS} \mathrm{l}^{-1}$ concentrations were used to estimate the lethal concentration $\left(\mathrm{LC}_{50}\right)$ level of the green grouper over the 6 wk exposure. From the $\mathrm{LC}_{50}$ data, biochemical and morphological measurements in the test fish were further examined in $4 \mathrm{SS}$ concentrations $(0,50,200$ and $2000 \mathrm{mg} \mathrm{l}^{-1}$ ). At the termination of the experiment, 5 fish from suspended solids concentrations 0, 50, 200 and $2000 \mathrm{mg} \mathrm{l}^{-1}$ were sampled and anaesthetized in Tricane methosulfonate $\left(0.1 \mathrm{~g} \mathrm{l}^{-1}\right)$. Blood was collected from the caudal vein of each fish using a haematocrit tube and centrifuged. Haematocrit value was determined and serum osmolarity measured using an osmometer (Wescor 5500 Vapopressure Osmometer). White muscle was dissected from the anterior of the fish, below the dorsal fin. The left gill arches were collected for light microscopy and scanning electron microscopy (SEM), and gill arches from the right were collected for ATPase measurements. Tissues for biochemical analysis were immediately frozen in liquid nitrogen, and stored at $-80^{\circ} \mathrm{C}$.

RNA:DNA ratio. Determination of RNA and DNA was based on Foss \& Forbes (1997). All chemicals were purchased from Sigma (USA). Muscle was chopped finely with a sterile scalpel blade, and homogenised in Tris-SDS buffer. Phenol:chloroform: isoamyl alcohol (25:24:1) was added to the homogenate for the first step of nucleic acid isolation. The sample was shaken and centrifuged at $3800 \times g$ for $10 \mathrm{~min}$ at $4^{\circ} \mathrm{C}$. The top aqueous layer was removed and chloroform:isoamyl alcohol (24:1) added to this fraction. The sample was shaken and centrifuged at $3800 \times g$ for $5 \mathrm{~min}$ at $4^{\circ} \mathrm{C}$. The top layer was removed and mixed with cold $0.05 \mathrm{M}$ Tris-buffer. The purified nucleic acid mixture was split into 2 Eppendorf pipettes. To obtain DNA only, one Eppendorf pipette was treated with RNAse, and both Eppendorf pipettes were incubated at $37^{\circ} \mathrm{C}$ for $30 \mathrm{~min}$. Samples were pipetted into a 96-well plate, and ethidium bromide added prior to reading. The spectrofluorometer (Floromax) was set at an excitation wavelength of 365 $\mathrm{nm}$ and emission wavelength of $590 \mathrm{~nm}$. The ratio of RNA:DNA was calculated by subtracting the fluorescence value of the blanks from that of each RNA and DNA sample, and then dividing the DNA fluorescence value by that of the RNA fluorescence.

ATPase. ATPase assay was conducted based on the methods of McCormick (1993), with minor modifications. Unless indicated, all chemicals were purchased from Sigma (USA). Gill filaments were removed from the gill arch and immersed in SEI (Sucrose-EDTA-Imidazole) buffer containing $150 \mathrm{mM}$ sucrose, $10 \mathrm{mM}$ EDTA, $50 \mathrm{mM}$ imidazole ( $\mathrm{pH}$ 7.3) and stored at $-80^{\circ} \mathrm{C}$ for no longer than 3 mo. A salt solution consisting of $189 \mathrm{mM} \mathrm{NaCl}, 10.5 \mathrm{mM} \mathrm{MgCl}, 42 \mathrm{mM} \mathrm{KCl}$, and $50 \mathrm{mM}$ imidazole ( $\mathrm{pH}$ 7.5) was prepared. Two assay solutions, designated Solutions A and B, were also prepared. Solution A was composed of 4 U lactate dehydrogenase $\mathrm{ml}^{-1}$ (Fluka), $5 \mathrm{U}$ pyruvate kinase $\mathrm{ml}^{-1}$ (Fluka), $2.8 \mathrm{mM}$ phosphoenolpyruvate (Fluka), $0.7 \mathrm{mM}$ ATP, $0.2 \mathrm{mM} \mathrm{NADH}, 50 \mathrm{mM}$ imidazole ( $\mathrm{pH} 7.5)$; and Solution B was as described above, but also contained $0.5 \mathrm{mM}$ oubain. Assay mixtures were composed of either Solution A or B, mixed with salt solution at a ratio of 3:1 and kept on ice. Immediately prior to use, solutions were placed in a $25^{\circ} \mathrm{C}$ water bath. Gill filaments were homogenised in SEI buffer that contained an additional $0.5 \mathrm{~g}$ sodium deoxycholate $100 \mathrm{ml}^{-1}$ buffer. The homogenate was centrifuged at $5000 \times g$ for 30 seconds. The microplate was kept cool and $25 \mu \mathrm{l}$ of homogenate was added to each of 4 wells. A volume of $100 \mu \mathrm{l}$ of Solution A in salt solution was added to 2 wells per sample, and $100 \mu$ l of Solution B in salt solution was added to the remaining 2 wells per sample. The microplate reader (Spectromax) temperature was set at $25^{\circ} \mathrm{C}$ and the wavelength set at $340 \mathrm{~nm}$. NADH disappearance was measured for $10 \mathrm{~min}$, at $1 \mathrm{~min}$ intervals. $\mathrm{Na}^{+}, \mathrm{K}^{+}$-ATPase activity was calculated as ATP hydrolysis in the presence and absence of oubain. $\mathrm{Na}^{+}, \mathrm{K}^{+}$-ATPase activity was reported as $\mu \mathrm{mol}$ ADP mg protein $^{-1} \mathrm{~h}^{-1}$. Protein content of the homogenate was measured using the Bradford Assay.

Serum T3. The levels of free T3 in serum were measured using the DPC Coat-a-Count kit (Catalogue No. TRK35). $100 \mu \mathrm{l}$ serum was pipetted into tubes coated with antibody, and incubated with ${ }^{125}$ I for 3 hours and decanted. Radioactivity was measured for 1 minute in a gamma counter (Packard). 
Gill pathology. Gill pathology of fish was studied using light microscopy (LM) and scanning electron microscopy (SEM). The second and third gill arches were removed from fish immediately after blood collection (within $30 \mathrm{~s}$ ). Isolated gill arches were rinsed and dissected in cold saline (containing $250 \mathrm{mM} \mathrm{Sac}-$ charose, $20 \mathrm{U} \mathrm{ml}^{-1}$ heparin, $12.5 \mathrm{mM} \mathrm{NaCl}$, and $5 \mathrm{mM}$ HEPES, pH 7.4) prior to fixation in buffered $2 \%$ paraformaldehyde and $2.5 \%$ glutaraldehyde (0.1 M cacodylate buffer at $\mathrm{pH} 7.6$ with $0.5 \% \mathrm{CaCl}_{2}$ ) for $24 \mathrm{~h}$ at $4{ }^{\circ} \mathrm{C}$. Fixed tissues were post-fixed in $2 \%$ osmium tetroxide at room temperature for $2 \mathrm{~h}$ before being dehydrated in a graded ethanol series and acetone.

For SEM studies, ethanol-acetone dehydrated samples were critical-point dried in liquid $\mathrm{CO}_{2}$ (Balzers Bal-Tec CPD 030). Dried tissues were mounted on stubs and sputter coated with gold palladium (Balzers Bal-Tec CED 030). The afferent side of gill filaments was examined using a Leica Stereoscan 440 at $20 \mathrm{kV}$.

For LM studies, dehydrated gill filaments were infiltrated and embedded in Spurr's resin. Tissue blocks were orientated so that the plane of sectioning was parallel to filaments and perpendicular to lamellae. Semi-thin sections (500 nm thick) were stained with $1 \%(\mathrm{w} / \mathrm{v})$ toluidine blue and examined under a bright field microscope (Olympus BX51).

SEM and morphometry: Chloride cell density (cell $\mathrm{mm}^{-2}$ ) was determined by SEM. The middle portion of a filament was examined at 1500×, which covered ca. $3500 \mathrm{~mm}^{2}$ of interlamellar area. Five fields were examined for each filament, and 3 filaments were studied for each fish. This yielded a total of 15 fields for each fish. Density of surface chloride cell was counted over the studied area and expressed as cells $\mathrm{mm}^{-2}$ (Bindon et al. 1994).

Light microscopy and stereology: At the LM level, a lamella is composed of an outer epithelial tissue region (T) and an inner pillar system (PS), which comprises flange tissues, pillar cells and blood channel. Between the T and PS is a non-tissue (NT) space. The stereological parameters determined were the volume densities of T, PS and NT within the lamella. Volume density, $\mathrm{Vv}_{\text {(structure, lamella) }}$ represents the volume fraction of lamella occupied by the structure/tissue investigated.

For each fish, 5 out of 8 embedded tissue blocks from each gill sample were randomly chosen for sectioning. One technically perfect section from each block was selected for LM examination. Five fields on each section were randomly selected according to the method of Howard \& Reed (1998), and the images of selected fields were captured and recorded by a CCD camera (JVC KY-F58), with a final magnification of 4900×. A total of 25 fields ( 5 fields $\times 5$ filaments) were studied for each fish. Stereological analysis was car- ried out on lamella using a Computer Assisted Stereological Toolbox (CAST) 2.0 (Olympus Denmark A/S). The volume densities lamella components were measured on LM image using a test point lattice with 192 points (test point distance, $d=4 \mu \mathrm{m}$ ). Points falling on the profiles of T, NT and PS inside a lamella, representing the volume densities of $\mathrm{Vv}_{\text {(epithelim tissue, lamella) }}$ $\left(V_{\mathrm{T}}\right), \mathrm{Vv}_{\text {(non-tissue space, lamella) }}\left(V_{\mathrm{NT}}\right)$ and $\mathrm{Vv}_{\text {(pillar system, }}$ lamella) $\left(V_{\mathrm{PS}}\right)$, were determined.

Respiratory stress on gill lamellae was studied by measuring changes in epithelium thickness, lifting of epithelium, and hyperplasia of pillar system. Relative thickness of epithelium is represented by percentage volume density of epithelial tissue $\left(V_{\mathrm{T}} / V_{\mathrm{L}}\right)$, where $V_{\mathrm{L}}$ is the volume density of lamella which is equivalent to $V_{\mathrm{T}}$ $+V_{\mathrm{NT}}+V_{\mathrm{PS}}$. Epithelium lifting is represented by percentage volume density of non-tissue space $\left(V_{\mathrm{NT}} / V_{\mathrm{L}}\right)$, while hyperplasia of the pillar system is represented by percentage $V_{\mathrm{PS}} / V_{\mathrm{L}}$.

Data analysis. ANOVA was used to test whether there was any significant difference in individual biological responses between control and the various levels of treatments. Normality of data distribution was tested prior to ANOVA. Where significant differences were identified $(p<0.05)$, pairwise comparisons between the control and each level of treatment were carried out using a Dunnett's test (Zar 1999). Percentage data were arcsin square-root transformed, whereas $\mathrm{Na}^{+}, \mathrm{K}^{+}$-ATPase data were log transformed to conform to data normality prior to analysis.

\section{RESULTS}

Over the experiment, dissolved oxygen ranged from 6.79 to $8.11 \mathrm{mg} \mathrm{l}^{-1}$, total and un-ionised ammonia were 0.01 to $1.64 \mathrm{mg} \mathrm{l}^{-1}$ and 0.001 to $0.103 \mathrm{mg} \mathrm{l}^{-1}$ respectively, salinity 30.0 to $30.9 \%$, temperature 19.0 to $21.6^{\circ} \mathrm{C}$, and $\mathrm{pH} 7.35$ to 7.85 . The measurement of total and un-ionised ammonia levels of 1.64 and $0.103 \mathrm{mg} \mathrm{l}^{-1}$ was only recorded once during Week 1 of the experiment. Apart from these records, the total and unionised ammonia levels were mostly between 0.01 and $0.20 \mathrm{mg} \mathrm{l}^{-1}$ and 0.001 and $0.013 \mathrm{mg} \mathrm{l}^{-1}$, respectively. Determination of suspended solids in water samples revealed that the actual exposure concentrations were maintained at 60 to $70 \%$ of nominal concentrations throughout the 6 wk exposure period.

\section{Mortality}

For the 6 suspended sediment concentrations $(0,50$, $100,200,1000$ and $\left.2000 \mathrm{mg} \mathrm{l}^{-1}\right)$, the mean $\%$ mortalities recorded over the $6 \mathrm{wk}$ experimental period were 
$0,30,20,30,40$ and 65, respectively. Only under SS of $2000 \mathrm{mg} \mathrm{l}^{-1}$ was fish mortality greater than $50 \%$. The 6 wk $\mathrm{LC}_{50}$ value estimated from graphical plots using the software ToxCalc (Tidepool Scientific Software) was $1400 \mathrm{mg} \mathrm{l}^{-1}$.

\section{Feed intake, growth and RNA:DNA ratio}

Feed intake and changes in weight are shown in Table 1. Two-way ANOVA showed no significant difference $(p=0.085)$ in feed intake between seawater control and the various levels of suspended solids treatments for the same time period, but feed intake in all treatment and control showed significant increase with time $(p<0.001)$.

Increase in wet weight was found in the control and treated fish by the end of the 6 wk exposure, and significant differences in wet weight were found among treatments $(p=0.002)$ and time $(p=0.005)$. However, no significant difference was found in RNA:DNA ratios between control and the various levels of treatments ( $p>0.05$ ) (Fig. 1).

\section{$\mathrm{Na}^{+}, \mathrm{K}^{+}$-ATPase activity, osmolarity, haematocrit value and T3}

$\mathrm{Na}^{+}, \mathrm{K}^{+}$-ATPase activity was significantly lower $(\mathrm{p}=$ 0.036) when fish were exposed to $2000 \mathrm{mg} \mathrm{SS}^{-1}$ as compared to the seawater control, while no change was found in lower concentrations (Fig. 2). No significant changes in serum osmolarity or haematocrit were measured in all levels of treatment (Figs. $3 \& 4$ ).

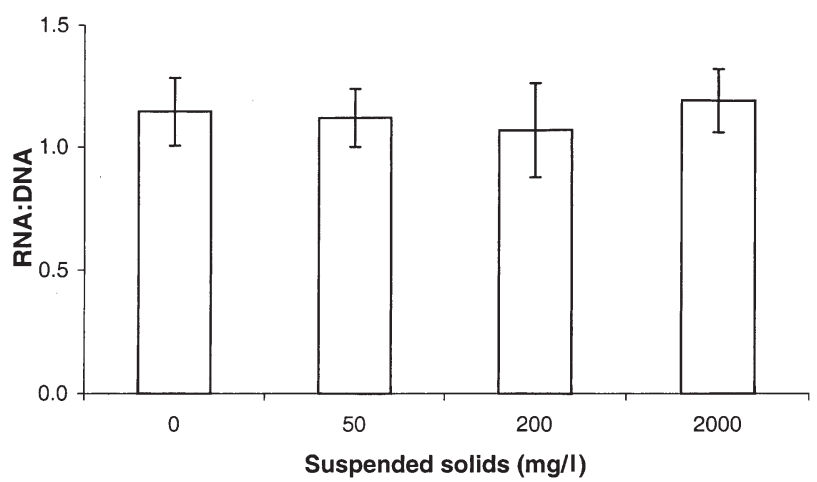

Fig. 1. Epinephelus coioides. Mean (SE) RNA:DNA ratio of grouper exposed to suspended solids for $6 \mathrm{wk}$. No significant differences from controls were calculated $(p>0.05)$
The concentrations of free T3 were lower when fish were exposed to $200(\mathrm{p}=0.035)$ and $2000 \mathrm{mg} \mathrm{SS}^{-1}$ $(p=0.049)$, compared to the control (Fig. 5). The T3 concentrations, however, were not concentrationdependent with increasing concentrations of SS.

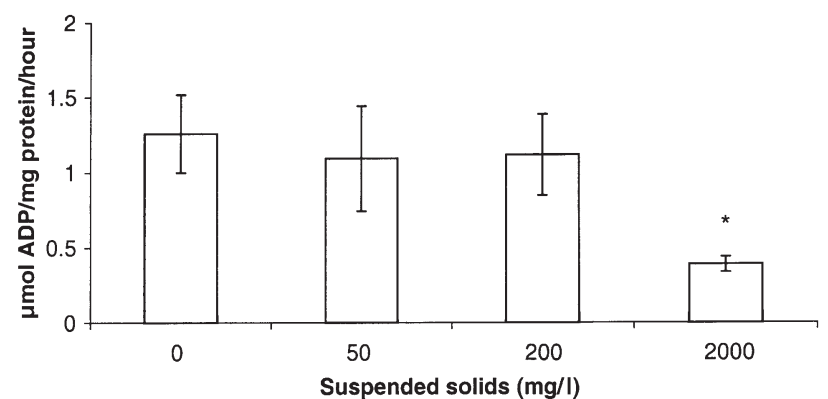

Fig. 2. Epinephelus coioides. Mean (SE) ATPase activity of grouper exposed to suspended solids for $6 \mathrm{wk}$. Asterisk denotes a significant difference from the control $(p<0.05)$

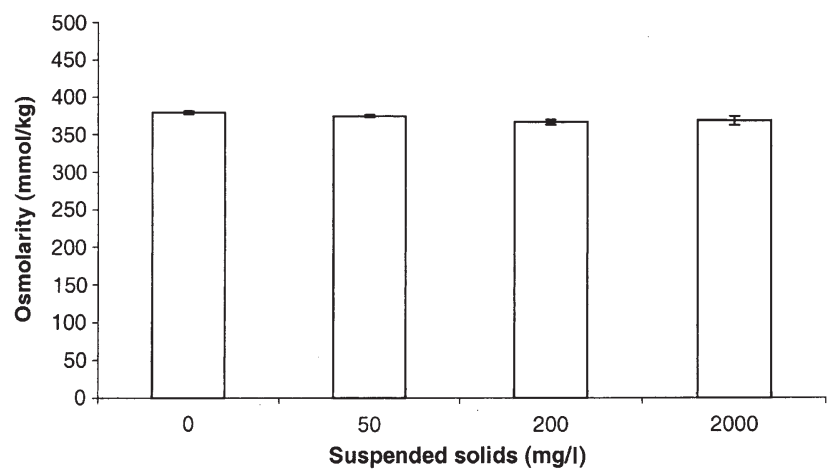

Fig. 3. Epinephelus coioides. Mean (SE) osmolarity of grouper exposed to suspended solids for $6 \mathrm{wk}$. No significant differences from controls were calculated $(p>0.05)$ 


\section{Gill pathology}

Chloride cell density. Chloride cells are commonly observed near the basal region of the lamellae (Fig. 6a). Upon exposure to SS, chloride cells became more distinct and abundant (Fig. 6b). The density of chloride

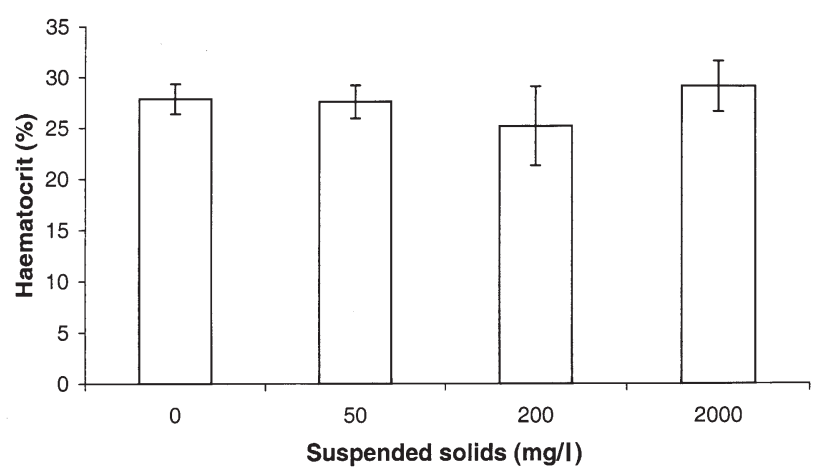

Fig. 4. Epinephelus coioides. Mean (SE) percentage haematocrit of grouper exposed to suspended solids for $6 \mathrm{wk}$. No significant differences from controls were calculated $(p>0.05)$

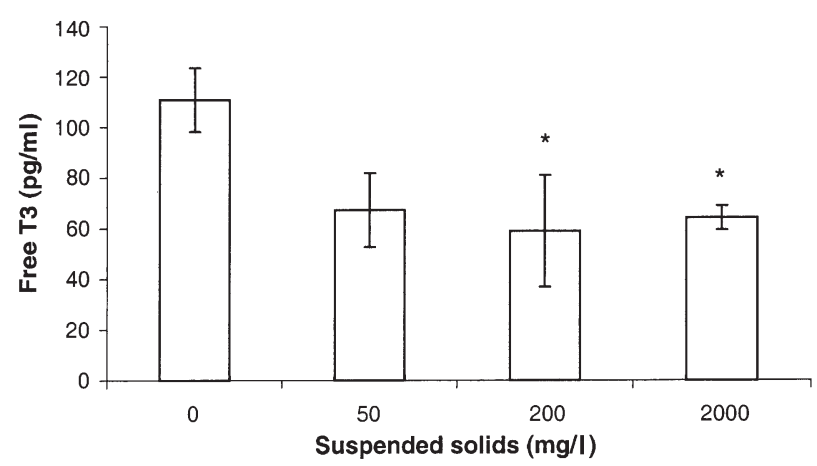

Fig. 5. Epinephelus coioides. Mean (SE) plasma concentrations of free triiodothyronine (T3) of grouper exposed to suspended solids for $6 \mathrm{wk}$. Asterisks denote a significant difference from the control $(p<0.05)$

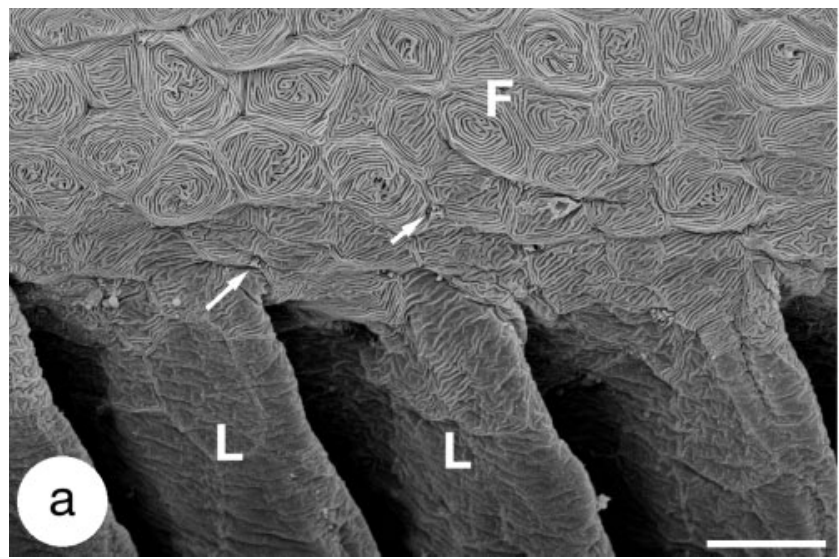

cells increased with concentrations of SS, and was significantly higher than that of the control at $2000 \mathrm{mg}$ $\mathrm{SS} \mathrm{l}^{-1}(\mathrm{p}<0.05)$ (Fig. 7).

Epithelium lifting. With control exposure, the nontissue space within epithelial tissue was inconspicuous (Fig. 8a). Epithelium lifting (Fig. 8b) increased (higher $V_{\mathrm{NT}} / V_{\mathrm{L}}$ ) in fish exposed to $\geq 200 \mathrm{mg} \mathrm{SS}^{-1}(\mathrm{p}<0.05)$ (Fig. 9a).

Epithelium thinning. Significant reduction in volume density of epithelium $\left(V_{\mathrm{T}} / V_{\mathrm{L}}\right)$ was found in lamellae exposed to $\geq 50 \mathrm{mg} \mathrm{SS} \mathrm{l}^{-1}$ ( $\mathrm{p}<0.01$ ) (Figs. 8 \& 9b). Epithelium thinning (percentage $V_{\mathrm{T}} / V_{\mathrm{L}}$ ) showed an inverse linear relationship to concentration of SS.

Hyperplasia of pillar system. Thickening of pillar system including hypertrophy and/or hyperplasia of flange tissues and enlargement of capillary space was observed (Fig. 8c). A significant increase in percentage $V_{\mathrm{PS}} / V_{\mathrm{L}}$ was found after exposure to $\geq 50 \mathrm{mg} \mathrm{SS} \mathrm{l}^{-1}$ $(\mathrm{p}<0.05)$ (Fig. 9c). A positive dose-response relationship was observed between concentrations of SS and percentage $V_{\mathrm{PS}} / V_{\mathrm{L}}$.

\section{DISCUSSION}

There is considerable variability in tolerance between test species to SS, with 'no effect' responses being measured in oyster toadfish Opsanu tau and spot Leiostomus xanthurus at $14000 \mathrm{mg} \mathrm{l}^{-1}$ for durations of $3 \mathrm{~d}$ or more (see review Wilber \& Clark 2001). In similar conditions, mortality has been observed in Atlantic silverside Menidia menidia at concentrations of $580 \mathrm{mg} \mathrm{l}^{-1}$ (see review Wilber \& Clark 2001). Sensitive fish species are classified as those having a $24 \mathrm{~h} \mathrm{LC}_{10}$ value $<10000 \mathrm{mg} \mathrm{l}^{-1}$ (Wilber \& Clark 2001), with bay anchovy Anchoa mitchilli, juvenile Atlantic menhaden Brevoortia tyrannus, striped bass Morone saxatilis,

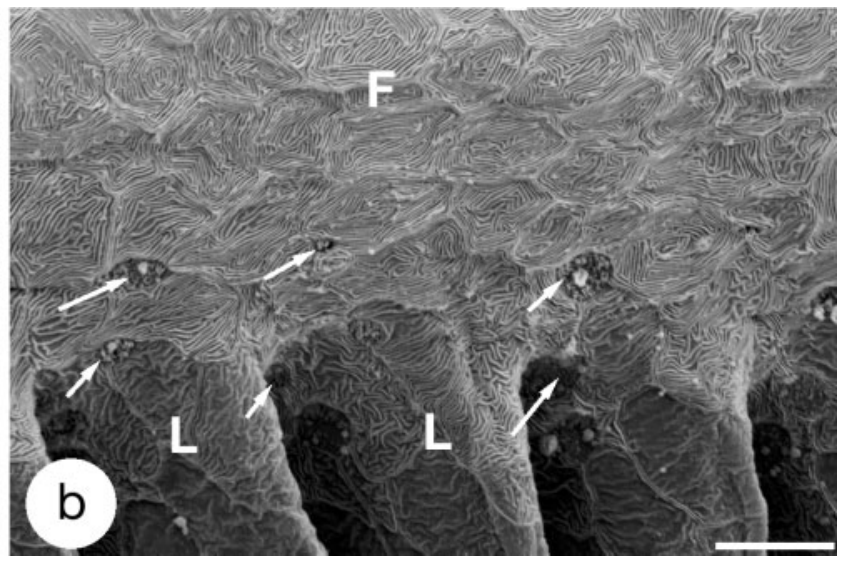

Fig. 6. Epinephelus coioides. SEM micrographs of gills. (a) Control. Chloride cells (arrowed) are randomly distributed in the interlamellar region of filament (F). L = lamella. (b) Gill exposed to $2000 \mathrm{mg} \mathrm{l}^{-1}$ of suspended solids. Chloride cells (arrowed) are more distinct and abundant in the interlamellar region as compared to that of the control (a). Scale bars $=10 \mu \mathrm{m}$ 


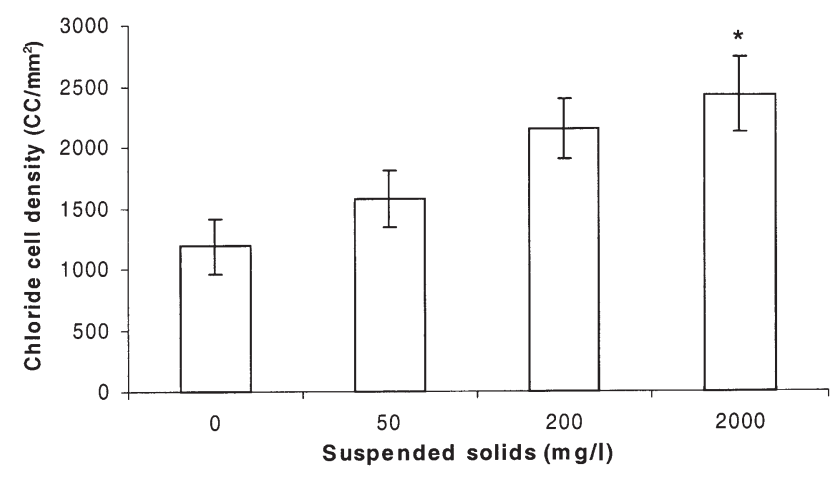

Fig. 7. Epinephelus coioides. Changes (mean $\pm \mathrm{SE}$ ) in chloride cell density in gills after exposure to different concentrations of suspended solids for $6 \mathrm{wk}$. Value with an asterisk indicates significant difference $(p<0.05)$ from the control

Atlantic croaker Micropognias undulatus, and weakfish Cynoscion regalis falling into this category. The $96 \mathrm{~h} \mathrm{LC}_{50}$ value of juvenile coho salmon Oncorhynchus kisutch was $164.5 \mathrm{mg} \mathrm{l}^{-1}$ sediment (Lake \& Hinch
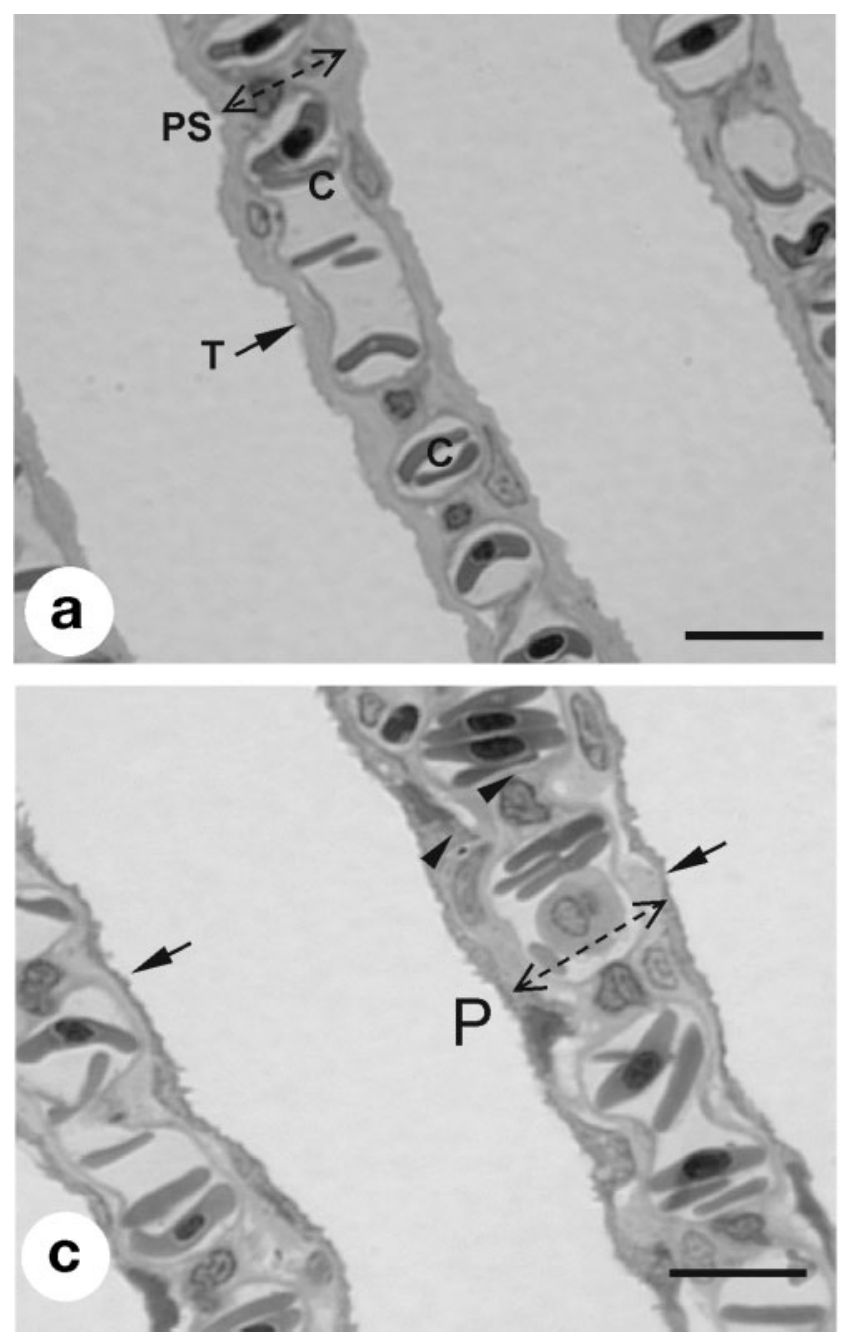

1999), and sediment was found to be clogging the gills of dead or morbid fish. Whilst direct comparison is not possible, owing to different experimental exposure periods and endpoints, it appears that the green grouper can tolerate a higher SS than other species reported in the literature. However, Lutjanus argentimaculatus, another native grouper species in Hong Kong, may show an even higher tolerance to acute effects of suspended solids than the green grouper, with less than $10 \%$ mortality $\left(\mathrm{LC}_{50}\right)$ in fish exposed to up to $5000 \mathrm{mg} \mathrm{SS} \mathrm{l}^{-1}$ over a period of $48 \mathrm{~h}$ (CCPC 2001).

It is generally assumed that mortality of fish upon exposure to suspended solids is caused by anoxia associated with gill impairment, impaired osmoregulation, reduced metabolic capacity, and reduced capability in clearing of sediment from gills (Servizi \& Martens 1991). Oxygen deprivation results from sediment coating the respiratory epithelia of fish, cutting off gas exchange with water (see review Wilber \& Clark 2001). In this study, no significant difference in weight gain was found in fish from the different treatments, nor in

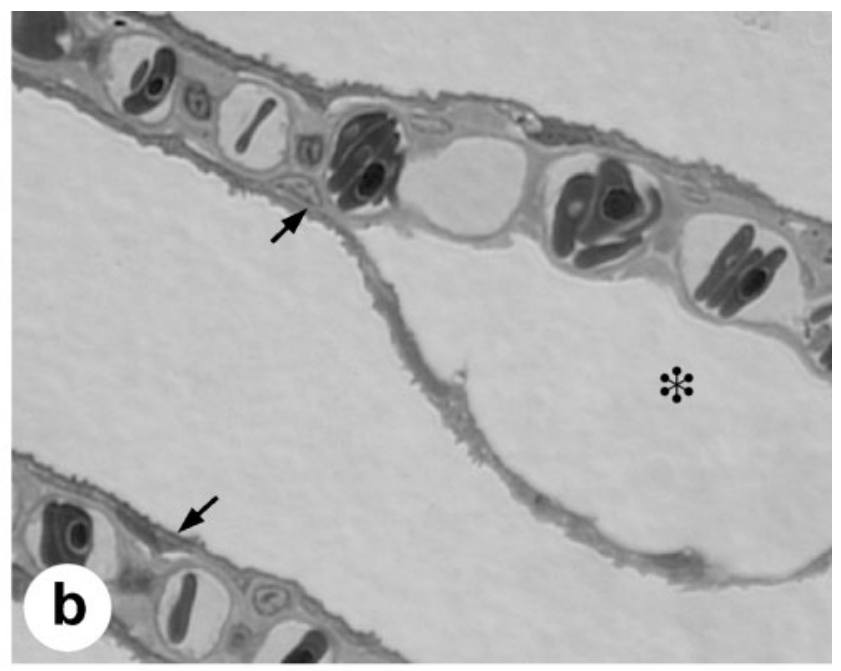

Fig. 8. Epinephelus coioides. Light micrographs of gills. (a) Control lamellae showing the epithelial tissue region (arrowed), the pillar system (PS), including both the flange tissues (arrowheaded) and the blood capillary (C). T = epithelium. Non-tissue space within the epithelial tissue is not conspicuous. (b) Gills exposed to $200 \mathrm{mg} \mathrm{l}^{-1}$ of SS. Non-tissue space (*:) underneath the epithelium region (arrowed) is obvious, leading to epithelium lifting. (c) Gills exposed to $2000 \mathrm{mg} \mathrm{l}^{-1}$ of SS, showing lamella with a thickening of PS including both the flange tissues (arrowheaded) and the blood capillary, a relatively thin epithelium tissue (arrowed). Scale bars $=10 \mu \mathrm{m}$ 

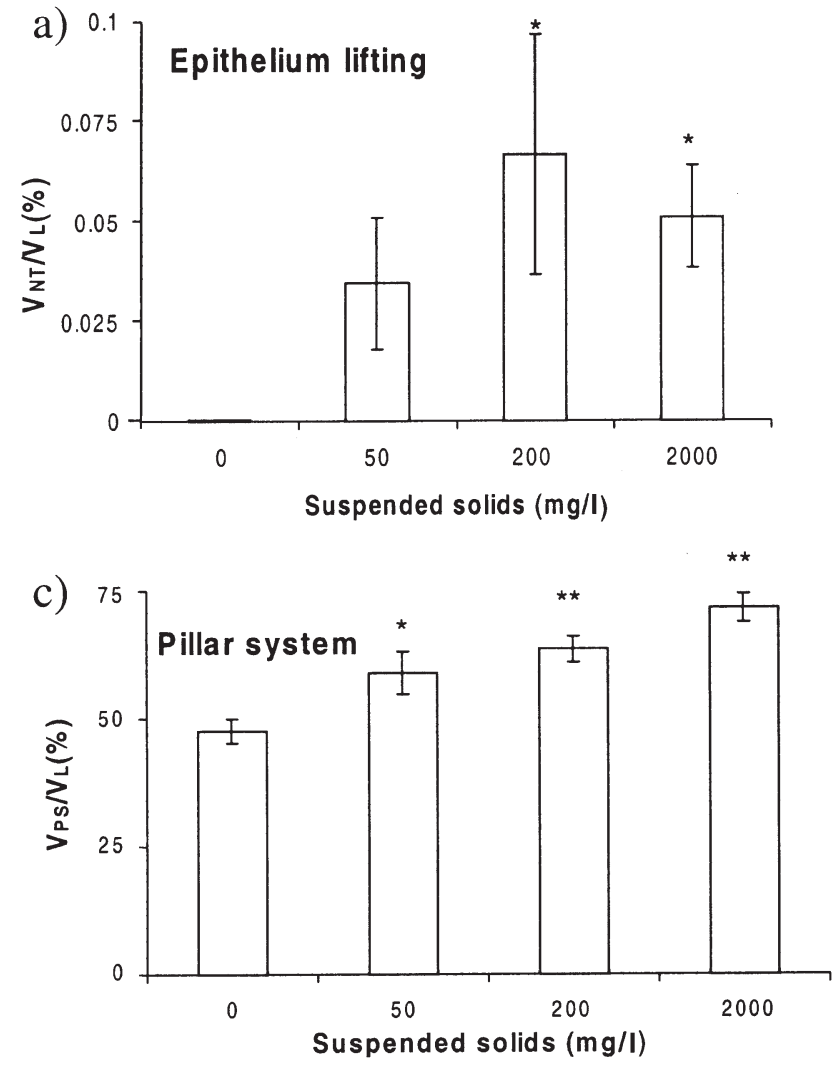

the RNA:DNA ratio, which is a very sensitive growth indicator (Zhou et al. 2000). Thus, in green grouper, suspended solids did not appear to reduce metabolic capacity to the extent that growth was affected, at least not over the duration of exposure. The fact that feed intake was not reduced by exposure to suspended solids either, but increased in all treatments as the experiment progressed, showed that the experimental fish could tolerate high SS with time.

The sublethal and acute effects of SS on fish is most likely due to mechanical abrasion and clogging of gills, leading to physical impairment at the gill surface (USEPA 1986). Short-term exposure of juvenile Pacific salmon Oncorhynchus spp. to $16-41 \mathrm{mg} \mathrm{SS} \mathrm{l}^{-1}$ for $96 \mathrm{~h}$ showed intracellular lodging of sediment particles into gill epithelia of the lamellae (Martens \& Servizi 1993). These results are consistent with our findings, with the lowest tested concentration, $50 \mathrm{mg}$ $\mathrm{SS}^{-1}$, showing structural gill damage in the green grouper. However, on the contrary, physical gill damage was reported in juvenile coho salmon exposed to concentrations of $>40000 \mathrm{mg} \mathrm{SS}^{-1}$ at near saturation of oxygen (Lake \& Hinch 1999). In our study, gill pathological symptoms observed in the green grouper included epithelial lifting, reduction of epithelial thickness and hyperplasia in the pillar system. These changes represent sublethal rather than

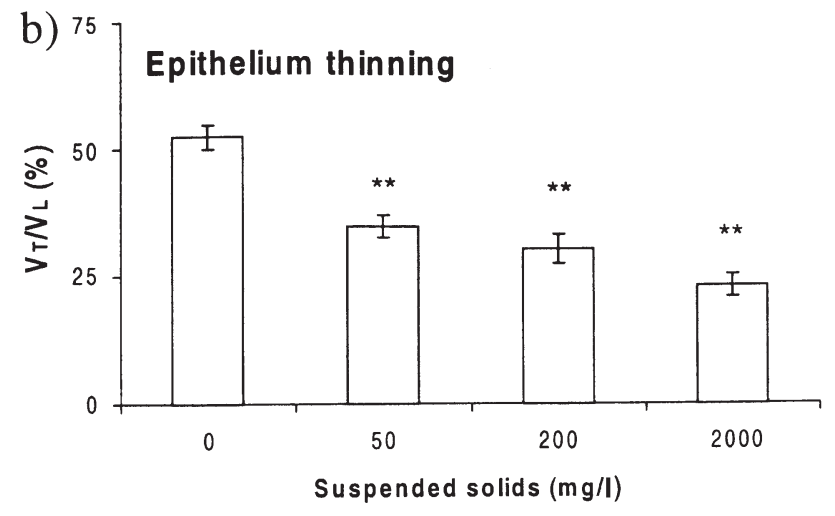

Fig. 9. Epinephelus coioides. Morphometric measurements (mean \pm SE) of lamellae. (a) Epithelium lifting, as represented by percentage $V_{\mathrm{NT}} / V_{\mathrm{L}}$. (b) Thickness of epithelium, as represented by percentage $V_{\mathrm{T}} / V_{\mathrm{L}}$. (c) Thickness of pillar system, as represented by percentage of $V_{\mathrm{PS}} / V_{\mathrm{L}}$. (See 'Light microscopy and stereology' for details.) Gills were exposed to different concentrations of suspended solids for $6 \mathrm{wk}$. Values with asterisks indicate significant difference from the control $(* \mathrm{p}<0.05 ; * \star \mathrm{p}<0.01)$

acute effects. Lifting of lamella epithelium is the most commonly reported lesion in fish gills upon exposure to waterborne pollutants such as heavy metals or organic hydrocarbons (Hughes et al. 1979, Mallatt 1985, Jagoe et al. 1996, Arellano et al. 1999). The suspended solids used in this study were not chemically contaminated and yet abrasion of the gills by sediment particles also induced epithelial lifting. Edema of lamella resulting from epithelium lifting would reduce the interlamellar space, which may impede water flow across the respiratory surface, causing respiratory stress in the fish. Soivio \& Heikrala (1981) showed that fish under hypoxic conditions developed symptoms of epithelium thinning, thickening of pillar cell system as well as a distension of the vasculature in gill lamellae. These responses are essential to facilitate gaseous exchange by shortening the diffusion distance and increasing the residence time for blood at the respiratory surface (Soivio \& Heikrala 1981). Similar gill pathological changes were observed in the SS-exposed green groupers, suggesting that the fish were under hypoxic stress.

The chloride cells on the gill filament are the site of sodium and chloride translocation, using $\mathrm{Na}^{+}, \mathrm{K}^{+}$ATPase to create ionic and electrical gradients that are used for salt secretion in seawater (Avella \& Bornancin 1989, McCormick 1993). Changes in chloride cell num- 
ber could lead to a corresponding change in $\mathrm{Na}^{+}, \mathrm{K}^{+}$ATPase activity (Lemaire-Gony et al. 1994). Our data showed a progressive increase of chloride cell density with increasing concentrations of suspended solids, becoming significantly different from the control at $2000 \mathrm{mg} \mathrm{SS}{ }^{-1}$. Similarly, $\mathrm{Na}^{+}, \mathrm{K}^{+}$-ATPase enzyme activity was significantly reduced at $2000 \mathrm{mg} \mathrm{SS} \mathrm{l}^{-1}$. This may be explained by the fact that the increase in number of chloride cells was able to maintain osmoregulatory processes via $\mathrm{Na}^{+}, \mathrm{K}^{+}$-ATPase at lower SS concentrations. However, at a high SS concentration of $2000 \mathrm{mg} \mathrm{l}^{-1}$, even an increase in chloride cells was unable to compensate for the respiratory distress experienced by the grouper.

Despite changes in $\mathrm{Na}^{+}, \mathrm{K}^{+}$-ATPase activity and an increase in chloride cells on the lamella, plasma haematocrit and osmolarity remained unchanged in fish at all exposure concentrations compared to the control. This finding is in agreement with Van den Heuvel et al. (2000), where proliferation of chloride cells in adult yellow perch Perca flavescens after exposure to oil sands and mining waters was not associated with decreases in plasma sodium, calcium or chloride. Prior studies have concluded that common sublethal responses to suspended solids exposures are an increase in red blood cell count, haematocrit and haemoglobin concentrations (see review Wilber \& Clark 2001). In this study, there are several possible interpretations: perhaps gill $\mathrm{Na}^{+}, \mathrm{K}^{+}$-ATPase activities were not altered to the extent where ion intake was altered, osmolarity may not be ion specific, and the change in overall ion concentration on the sera was unchanged, or ions in sera were retained in the gills.

Currently, there is insufficient scientific knowledge to determine with certainty what level of changes of SS from baseline conditions will cause adverse ecological effects (Mapstone 1995). Lloyd (1987) examined the turbidity standard to protect aquatic habitat for salmonid fish in the USA, and standards for the 9 examined states varied between 10 and $20 \%$ above background value, which is obtained from monitoring data and site specific. In Europe, the 1979 Directive to protect marine shellfish water stipulated that SS should not increase by more than $30 \%$. In Hong Kong, no continuous concentration criterion of suspended solids has been established, and only a maximum concentration of $50 \mathrm{mg} \mathrm{SS} \mathrm{l}^{-1}$ is recommended as a guideline. In this study, results of histological examination of fish gills suggest that acute oxygen deprivation is unlikely to occur at $50 \mathrm{mg} \mathrm{SS} \mathrm{l}^{-1}$; at this concentration, fish may experience minor respiratory distress, as indicated by changes in pillar system and epithelial thinning. At concentrations of $200 \mathrm{mg} \mathrm{SS}^{-1}$, in addition to respiratory distress, T3 concentrations in the plasma were elevated, indicating that growth and develop- ment may be potentially disrupted. At $2000 \mathrm{mg} \mathrm{l}^{-1}$, respiratory distress was considerable, and plasma T3 remained disrupted; however, growth in the shortterm was not disturbed. Although suspended solids concentrations of $1000 \mathrm{mg} \mathrm{l}^{-1}$ or above are considered to be very high and environmentally unrealistic in the marine ecosystem (even in the vicinity of dredging and dumping sites), concentrations below this level are still of concern. Hayes et al. (2000) reported SS of $500 \mathrm{mg} \mathrm{l}^{-1}$ within $500 \mathrm{~m}$ of a hydraulic dredging operation, and maybe even up to $800 \mathrm{mg} \mathrm{l}^{-1}$ as far as $1200 \mathrm{~m}$ away from a hopper dredger (LaSalle 1990). Our experiments demonstrate that although suspended solids in this range are unlikely to cause mortality in green grouper after prolonged exposure, sublethal changes due to respiratory distress, adverse growth and developmental effects are likely to occur in the long-term if exposures continue.

In this study, fish were exposed to sediment which is not chemically contaminated. In the coastal environment, suspended sediments frequently serve as a sink for contaminants. These contaminants can be resuspended into the water column by dumping and dredging (Cope et al. 1996). A study by Wong et al. (1995), for example, found that sediments in Victoria Harbour, Hong Kong, were severely contaminated with heavy metals and organic compounds, especially near urbanised centres and industrialised areas. These chemicals can cause sublethal stress, and in combination with SS, may have important interactive effects on marine fishes. Further studies are required to determine the effect of combined stressors of suspended solids and associated contaminants on marine species.

\section{LITERATURE CITED}

APHA (American Public Health Association) (1995) Standard methods for the examination of water and wastewater, 19th edn. APHA, Washington, DC

Arellano JM, Storch V, Sarasquete C (1999) Histological changes and copper accumulation in liver and gills of the Senegales Sole, Solea senegalensis. Ecotoxicol Environ Saf 44:62-72

Avella M, Bornancin M (1989) A new analysis of ammonia and sodium-transport through the gills of the freshwater rainbow trout (Salmo, Gairdner). J Exp Biol 142:155-175

Bindon SD, Gilmour KM, Fenwick JC, Perry SF (1994) The effects of branchial chloride cell proliferation on respiratory function in the rainbow trout Oncorhynchus mykiss. J Exp Biol 197:47-63

Bruton MN (1985) The effects of suspended solids on fish. Hydrobiologia 125:221-241

CCPC (Centre for Coastal Pollution and Conservation) (2001) Agreement no. CE 62/98. Consultancy study in fisheries and marine ecological criteria for impact assessment. Centre for Coastal Pollution and Conservation, City University of Hong Kong, Hong Kong

CCREM (Canadian Council of Resource and Environment 
Ministers) (1987) Total suspended solids. In: Canadian Environmental Quality Guidelines. Environment Canada, Ottawa

Cope WG, Wiener JG, Steingraeber MT (1996) Test system for exposing fish to resuspended, contaminated sediment. Environ Pollut 91:177-182

DFO (Department of Fisheries and Oceans) (2000) Effects of sediment on fish and their habitat. Pacific Region Habitat Status Report 2000/01. DFO, Nanaimo

EIFAC (European Inland Fisheries Advisory Commission) (1964) Water quality criteria for European freshwater fish. Report (EIFAC/1) on finely divided solids and inland fisheries. European Inland Fisheries Advisory Commission. Food and Agriculture Organization of the United Nations, Rome

EPD (Environmental Protection Department) (2002) Marine water quality in Hong Kong in 2001. Environmental Protection Department, Government of Hong Kong SAR, Hong Kong

Foss HE, Forbes VE (1997) Effects of the polycyclic aromatic hydrocarbon fluoranthene on growth rate and nucleic acid composition of Capitella sp. I. Mar Biol 129:489-497

Hayes DF, Crockett TR, Ward TJ, Averett D (2000) Sediment resuspension during cutterhead dredging operations. J Waterw Port Coast Ocean Eng 126:153-161

Howard CV, Reed MG (1998) Unbiased stereology. Threedimensional measurement in microscopy. BIOS Scientific Publishers Limited, Guildford

Hughes GM, Morgan, M (1973) The structure of fish gills in relation to their respiratory function. Biol Rev 48:419-475

Hughes GM, Perry SF, Brown VM (1979) A morphometric study of effects of nickel, chromium and cadimum on the secondary lamellae of rainbow trout gills. Water Res 13: 665-679

Jagoe CH, Faivre A, Newman MC (1996) Morphological and morphometric changes in the gills of mosquitofish (Gambusia holbrooki) after exposure to mercury (« $2 »)$. Aquat Toxicol 34:163-183

Karnaky KJ, Kinte, LB, Kinter WB, Stirling CE (1976) Teleost chloride cell. J Cell Biol 70:157-177

Lake RG, Hinch SG (1999) Acute effects of suspended sediment angularity on juvenile coho salmon (Oncorhynchus kisutch). Can J Fish Aquat Sci 56:862-867

LaSalle MW (1990) Physical and chemical alterations associated with dredging. In: Simenstad CA (ed) Proc Workshop on the Effects of Dredging on Anadromous Pacific Coast Fishes. Washington Sea Grant Program, Seattle, p 1-12

Laurent P, Perry SF (1991) Environmental effect of fish gill morphology. Physiol Zool 64:4-25

Lemaire-Gony S, Lemaire P, Pulsford AL (1994) In vitro doseresponse study of the effects of cadmium on eel (Anguilla anguilla) $\mathrm{Na}^{+}, \mathrm{K}^{+}$-ATPase activities. Ecotoxicol Environ Saf 28:43-52

Lloyd DS (1987) Turbidity as a water quality standard for salmonid habitats in Alaska. N Am J Fish Manage 7:34-45

Mallatt J (1985) Fish gill structural changes induced by toxicants and other irritants: a statistical review. Can J Fish Aquat Sci 42:630-647

Mapstone BD (1995) Scalable decision rules for environmen-

Editorial responsibility: Charles Birkeland (Contributing

Editor), Honolulu, Hawaii, USA tal impact studies: effect size, Type I, and Type II Errors. Ecol Appl 5:401-410

Martens DW, Servizi JA (1993) Suspended sediment particles inside gills and spleen of juvenile Pacific salmon (Oncorhynchus spp.). Can J Fish Aquat Sci 50:586-590

McCormick S (1993) Methods of nonlethal gill biopsy and measurement of $\mathrm{Na}^{+}, \mathrm{K}^{+}$-ATPase activity. Can J Fish Aquat Sci 50:656-658

Metzeling L, Doeg T, O'Connor W (1995) The impact of salinization and sedimentation on aquatic biota. In: Bradstock RA, Auld TD, Keith DA, Kingsford RT, Lunney D, Silvertsen DP (eds) Conservation biodiversity: threats and solutions. Surrey Beatty, London

Newcombe CP, MacDonald DD (1991) Effects of suspended sediments on aquatic ecosystems. N Am J Fish Manage 11:72-82

Perry SF, Laurent P (1993) Environment effect on fish gill structure and function. In: Rankin JC, Jenson FB (eds) Fish ecophysiology. Chapman \& Hall, London, p 231-264

Randall DJ, Daxboeck (1984) Oxygen and carbon dioxide transfer across fish gills. In: Hoar WS, Randall DJ (ed) Fish physiology, Vol. XA. Academic Press, Orlando, p 263-314

Randall DJ, Wright PA (1987) Ammonia distribution and excretion in fish. Fish Physiol Biochem 3:107-120

Redding JM, Schreck CB, Everest FH (1987) Physiological effects on coho salmon and steelhead of exposure to suspended solids. Trans Am Fish Soc 116:737-744

Servizi JA, Gordon RW (1990) Acute lethal toxicity of ammonia and SS mixtures to Chinook salmon (Oncorhynchus tshawytscha). Bull Environ Contam Toxicol 44:650-656

Servizi JA, Martens DW (1991) Effect of temperature, season, and fish size on acute lethality of suspended sediments to coho salmon, Oncorhynchus kisutch. Can J Fish Aquat Sci 48:493-497

Soivio A, Heikrala K (1981) Structural and circulatory responses to hypoxia in the secondary lamellae of Salmo gairdneri gills at two temperatures. J Comp Physiol 145:37-43

USEPA (United States Environmental Protection Agency) (1986) Quality criteria for water. Report No. EPA 440/5 86-001. US Department of Commerce, Virginia

Van den Belt K, Puynbroek SV, Witters H (2000) Toxicity of cadmium-contaminated clay to the zebra fish Danio rerio. Arch Environ Contam Pollut 38:191-196

Van den Heuvel MR, Power M, Richards J, MacKinnon M, Dixon DG (2000) Disease and gill lesions in yellow perch (Perca flavescens) exposed to oil sands mining-associated waters. Ecotoxicol Environ Saf 46:334-341

Wilber DH, Clarke DG (2001) Biological effects of suspended sediments: a review of suspended sediment impacts on fish and shellfish with relation to dredging activities in estuaries. N Am J Fish Manage 21:855-875

Wong YS, Tam, NFY, Lau PS, Xue XZ (1995) The toxicity of marine sediments in Victoria Harbour, Hong Kong. Mar Pollut Bull 31:464-470

Zar JH (1999) Biostatistical analysis. Prentice Hall, Englewood Cliffs, NJ

Zhou BS, Wu RSS, Randall DJ, Lam PKS (2000) Effects of hypoxia on bioenergetics and RNA/DNA ratio of the common carp, Cyprinus carpio. J Comp Physiol 171:49-57

Submitted: May 28, 2003; Accepted: October 14, 2003

Proofs received from author(s): January 21, 2004 